\title{
List of terms and abbreviations
}

AMWU Australian Manufacturing Workers' Union

bookbinder A tradesperson fully indentured into the trade of bookbinding caster See Monotype caster

chapel A branch of a trade union or guild

chase A heavy metal frame upon which metal type and blocks were placed, held together and ready for the letterpress process

cold composition The setting of type with the aid of computers and phototypesetting, not with the use of hot metal

cold type See cold composition

Comp-Edit An early program for phototypesetting (cold composition) using word processors at the NSW Government Printing Office, used from 1980

comp/comps Slang word for compositor/s

composing stick A tool used by compositors to set lines of text from individual metal letters

composition The process of producing and assembling moveable type into lines, pages and formes, ready for letterpress printing

compositor A person who set the type prior to printing, in hot metal or by keyboarding

computer phototypesetting Electronic typesetting using a computer program

CSA City of Sydney Archives

diss The post-printing process of removing type from set pages and formes and replacing it into their typecases

dry-offset A printing method that used photosetting principles to produce a printing plate with a raised surface, meaning that letterpress principles and work practices remained, but the printing could take place on a lithographic machine

dustcoat Minimal protective clothing, particularly worn in the photographic and lithographic sections of the Government Printing Office in the 1960s and 1970 s

EEO Equal Employment Opportunity

electrotyping The process of producing a printing plate made from a mould and coated with nickel or copper 
embossing A labour-intensive process that enables a printed surface to stand out in relief

etaoin-shrdlu The top line of letters of a Linotype keyboard. The made-up words were used to signify the Linotype keyboard layout

feeder See Machine-feeder

flatbed press A letterpress printing machine where the printing plate lies flat on the bed and the impression cylinder and paper are rolled over it

FoC Father of the Chapel: the full-time union official who represented the printers' union branch or chapel

font room The room in which supplies of loose type (made by Monotype machines) was maintained and used by hand-compositors to refill their typecases

foreign orders Colloquial term for an object that is produced by an employee in the workplace - made from workplace materials and/or scrap, using in-house machinery - produced in an unauthorised manner. Known variously as homers, la perruque, and government jobs, among other terms

foreigners Term used in Queensland and Western Australia for foreign orders

foreignies Term used in South Australia for foreign orders

forme A complete set of metal type, assembled in a chase for letterpress printing

furniture Small pieces of wood wedged around the edge of a metal forme to keep the pages of type tight. Also used for blank spaces on a page

galley A long metal tray holding text in metal type. Also used to mean 'galley proof' - see galley proof

galley proof A proof in the form of a long piece of text, usually not divided into pages but printed on a long, continuous sheet of paper

galley trucks A trolley with wheels used to transport galleys

Gov, the Colloquial term for the NSW Government Printing Office

Graphic Reproduction A section within the Government Printing Office that encompassed photographic reproduction, etching, engraving, camera operation and other forms of graphic rendering

half-calf Also known as 'half-leather', a form of bookbinding where the corners and spine of the book were in very soft leather, and the rest of the binding was made of cloth

hand-binding Bookbinding undertaken chiefly by hand, using hand tools, not mass-production machinery

hand-compositor A compositor who worked in imposition, headers, layout, etc. in a composing room, assembling pieces of metal type, rather than using a hot-metal typesetting machine

Heidelberg cylinder A cylinder letterpress machine manufactured by Heidelberg homers A term used in the USA for foreign orders

hot-metal typesetting A method of type composition that involved casting molten metal into type forms and assembling it into pages and formes

imposition The act of arranging pages of type, or films, so that when a large sheet was printed, each page was in the right order and the correct way up for cutting and folding. With metal type this took place on a large, flat imposing stone or 'slab'. Once the pages were in the correct order they were locked into a chase for printing on a press

imposition slab The large flat table or stone surface used for imposition (see imposition)

la perruque The French term, popularised by Michel de Certeau, for foreign orders leading hand A senior tradesperson 
letterpress The process by which a raised surface of metal or wooden type was covered in ink and paper pressed onto it to produce a printed image

Linotype machine The most widely known type of hot-metal typesetting machine It was a linecasting machine used for producing single lines of type that were assembled by compositors to make a page. It came into widespread use in the late nineteenth century

Linotype operator Tradesperson who operated a Linotype machine. This job was seen as a high-status role in the printing industry

lithographic dot-etching The etching of an image through lithographic principles of oil and water to produce an image on a plate, which was then transferred to paper. This method dealt in making half tones darker or lighter, using hand etching to reduce or increase the size of the dots

litho Slang for lithography

lithography A method of printing in which ink adheres to greasy areas of heated metal, stone or film and then is transferred to paper. Originally using a stone plate, lithography was updated in the second half of the twentieth century for high-speed lithographic presses, using the same principle but with a metal plate. See also offset-lithography

Ludlow machine A hot-metal composing machine used to make type in large point sizes, for tasks such as headings, invitations and titles

machine-feeder An employee who fed paper into presses before machine-feeding presses were available. This role was usually given to low-paid non-tradespersons, often women

makeready The act of getting a print machine ready for printing. It involved getting the plates set up and testing the alignment, the paper, the ink levels and the quality of the impression

Masonic Lodge An organisational unit of Freemasonry - a fraternity with traditions tracing back to the stonemasons' guilds in the sixteenth century

Monotype casting machine A large casting machine that processed punched paper Monotype tape, in order to produce individual metal letters of type

Monotype caster An indentured tradesperson who operated a Monotype casting machine

Monotype machine A typesetting machine used to produce individual letters (rather than lines) of type. With a Monotype machine, the compositor typed on a keyboard, producing punched paper tape, which was then fed into a casting machine to generate individual letters

Monotype operator An indentured tradesperson who operated a Monotype keyboard. This was seen as a high-status trade in the printing industry

NSW The Australian state of New South Wales

NSWSR New South Wales State Records

NSWTA New South Wales Typographical Association

offset-lithography The same principle of printing as lithography, except the image on the plate was transferred to an offset cylinder, and from there it was printed onto paper

offsider The assistant to a printing tradesperson

overseer The supervisor of a particular industrial section in a factory

Penta The computer typesetting system in use at the NSW Government Printing Office from 1984 to 1989

perquisites Non-monetary benefits or privileges provided to workers. The taking of material in-kind perquisites was customary practice in feudal England 
and the rise of industrial capitalism and centralised legalistic order criminalised long-established customary practices, often redefining them as theft

photo-engraving The process of preparing image-based letterpress plates for printing, usually from photographs or illustrations.

photo-polymer plates A printing plate that had a layer of photosensitive plastic material bonded to a flexible metal (often aluminium) plate

phototypesetting A method of typesetting that produced characters using a computer and exposing light-sensitive film in front of a mask. This method superseded hot-metal typesetting

piecework Labour that was/is paid at a set rate per unit produced

PIEUA Printing Industries Employees' Union of Australia (1916-66)

PKIU Printing and Kindred Industries Union (1966-95)

punter Australian colloquialism for 'gambler', also used to denote a bidder at an auction, a customer at a brothel, or a voter

press-machinist The indentured tradesperson who operated press machinery

reader's assistant The assistant who read the original copy aloud to the proofreader, who checked the galley proof and marked up corrections

qwerty The standard keyboard layout in English-speaking countries

setting stick See composing stick

slug A line of type, typically produced by a Linotype machine

SLNSW State Library of New South Wales

Speedmaster A model of Heidelberg lithographic press from the 1970s that could be modified to handle letterpress, through a process known as dry-offset

stereotyping A type of printing plate developed in the late eighteenth century and used in letterpress runs. It involved making a mould or mat of papiermâché, and the dried mat was used to cast a stereotype from hot metal

tablehand Low-paid general assistant in printing, composing and bookbinding, who undertook repetitive tasks not assigned to indentured tradespeople. At the Government Printing Office, tablehands were often women and/or migrants

timehand This term was used to delineate between a pieceworker and a normal employee. Timehands were paid for the hours that they worked, not the amount they produced

tradesperson An employee who has completed a full apprenticeship and is employed in his or her trade

typecases The wooden containers that held individual metal pieces of type

type stick See composing stick

Unix A computer operating system first developed in the late 1970s 